\title{
Influence of radial pressure gradients on solute exchange in stirred benthic chambers
}

\author{
Ronnie Nøhr Glud*, Stefan Forster, Markus Huettel \\ Max-Planck-Institute for Marine Microbiology, Celciusstr. 1, D-28359 Bremen, Germany
}

\begin{abstract}
Bromide was used as a conservative tracer for evaluatung the effect of stirring-induced radial pressure gradients in 2 typical benthic chamber designs. One chamber was square, with side lengths of $30 \mathrm{~cm}$ (volume $9.0 \mathrm{l}$ ), and the other was cylindrical, with a diameter of $19 \mathrm{~cm}$ (volume $2.5 \mathrm{l}$ ). It was demonstrated that radial pressure gradients associated with chamber water rotation could induce advective porewater transport in both chambers. The intensity of the advective porewater transport was a function of sediment permeability and stırring rate. Stirred at $12 \mathrm{rpm}$, solute transport changed from diffusive to advective at a sediment permeability $>2 \times 10^{-12}$ in the square chamber and $>5 \times 10^{-12} \mathrm{~m}^{-2}$ in the cylindrical chamber. The sediment permeability at which solute exchange was still controlled by diffusion could be increased by almost 1 order of magnitude in the square chamber by decreasing the stirring rate to $7 \mathrm{rpm}$. The sediment permeability values can be used as a guide to when benthic chamber experiments can be performed without introducing a serious stirring-induced artefact.
\end{abstract}

KEY WORDS: Lander Benthic exchange. Flux chambers Convection Pressure gradients Bromıde

\section{INTRODUCTION}

In the last 30 yr benthic chambers have been an important tool for measuring benthic solute exchange in situ. Sophisticated free operating lander systems have evolved from simple bell jars placed on the sea floor by divers, (e.g. Pamatmat \& Banse 1969, Smith et al. 1976, Sayles \& Dickinson 1991, Glud et al. 1995). In most studies $\mathrm{O}_{2}$ has been the solute of greatest interest, since the total $\mathrm{O}_{2}$ uptake of sediments can be used as a measure of total benthic community respiration (e.g Smith \& Hinga 1983). A major consideration in deploying benthic chambers is stirring of the water phase, which in general serves 2 purposes: it mixes the overlying water, so that any sampling or water phase measurements reflect the average conditions inside the chamber, and it simulates as closely as possible the hydrodynamic conditions at the undisturbed seafloor.

Close to the surface of impermeable cohesive sediments, surface friction retards the flow to the extent

\footnotetext{
•E-mail: ronnje@postgate.mpi-mm.uni-bremen.de
}

that it becomes dominated by viscous forces. At the bottom of the millimetres thick viscous sublayer, eddy diffusion becomes suppressed to the extent that molecular diffusion becomes the most important transport mode for solutes. The transition from a uniform distribution of solutes in the turbulent layer to a linear diffusion gradient in the diffusive boundary layer (DBL) is generally observed 0.2 to $1.2 \mathrm{~mm}$ above the sediment surface (Archer et al. 1989, Gundersen \& Jorgensen 1990, Glud et al. 1994b). Despite the modest thickness of the DBL, it can impose an important diffusion barrier, limiting benthic-solute exchange and especially the $\mathrm{O}_{2}$ uptake of sediments (e.g Boudreau \& Guinasso 1982, Jørgensen \& Des Marais 1990).

Several studies have attempted to model and describe the hydrodynamics inside bell jars and benthic chambers, with specific emphasis on the DBL thickness during chamber incubations (e.g Santschi et al. 1983, Berelson \& Hammond 1986, Devol 1987. Buchholz-ten Brink et al. 1989, Sayles \& Dickinson 1991, Glud et al. 1995). It has been shown that through central stirring of benthic chambers it is possible to generate an average DBL thickness that corresponds 
Table 1. Characteristics of sediment collected from Sylt, Germany, and used in benthic chamber experiments. nm: not measured Porosity is given for the upper $7 \mathrm{~cm}$ only. Numbers in parentheses indicate number of measurements

\begin{tabular}{|c|c|c|c|c|c|c|c|c|}
\hline \multirow[t]{2}{*}{ Expt } & \multicolumn{6}{|c|}{ Grain-size distribution $(\%)$} & \multirow{2}{*}{$\begin{array}{c}\text { Average porosity } \\
\text { vol/vol }\end{array}$} & \multirow{2}{*}{$\begin{array}{c}\text { Permeability } \\
\left(\mathrm{m}^{2}\right)\end{array}$} \\
\hline & $>1000 \mu \mathrm{m}$ & $>500 \mu \mathrm{m}$ & $>250 \mu \mathrm{m}$ & $>125 \mu \mathrm{m}$ & $>63 \mu \mathrm{m}$ & $<63 \mu \mathrm{m}$ & & \\
\hline 1 & 0.1 & 0.8 & 33.6 & 64.5 & 2.4 & 0.0 & 0.39 & $1.74 \times 10^{-11} \pm 9.2 \times 10^{-13}(3)$ \\
\hline 2 & 0.2 & 32.6 & 64.5 & 2.2 & 0.2 & 0.0 & 0.34 & $5.69 \times 10^{-11} \pm 4.3 \times 10^{-13}(3)$ \\
\hline 3 & 0.0 & 0.6 & 7.3 & 85.2 & 6.5 & 0.1 & 0.39 & $4.82 \times 1.0^{-12} \pm 3.1 \times 10^{-14}$ \\
\hline 4 & 0.2 & 16.8 & 52.0 & 29.8 & 1.0 & 0.0 & 0.38 & $1.14 \times 10^{-13} \pm 6.67 \times 10^{-14}(3)$ \\
\hline 5 & $\mathrm{~nm}$ & $\mathrm{~nm}$ & $n m$ & $\mathrm{~nm}$ & $\mathrm{~nm}$ & $n m$ & 0.53 & $6.55 \times 10^{-14} \pm 3.2 \times 10^{-15}(3)$ \\
\hline 6 & 0.0 & 0.2 & 15.0 & 81.7 & 2.9 & 0.2 & 0.40 & $3.33 \times 10^{-11} \pm 8.5 \times 10^{-12}(15)$ \\
\hline 7 & 0.0 & 0.2 & 10.7 & 63.0 & 21.4 & 4.7 & 0.45 & $3.32 \times 10^{-12} \pm 3.6 \times 10^{-13}(10)$ \\
\hline 8 & 0.0 & 0.2 & 1.2 .3 & 70.0 & 14.5 & 3.0 & 0.43 & $4.38 \times 1.0^{-12} \pm 3.6 \times 10^{-14}(5)$ \\
\hline 9 & 0.0 & 0.2 & 13.9 & 77.1 & 7.5 & 1.3 & 0.40 & $7.98 \times 10^{-12} \pm 3.9 \times 10^{-14}(5)$ \\
\hline
\end{tabular}

to values measured in situ. In some cases the DBL thickness has been shown to be relatively constant over most of the base area (Buchholz-ten Brink et al. 1989, Glud et al. 1995). However, the rotating flow created by central stiring does impose a radial pressure gradient on the sediment. In cylindrical chambers (diameter $30 \mathrm{~cm}$ ) deployed in permeable sediments, this pressure gradient may induce an advective porewater transport, increasing benthic solute exchange (Booij et al. 1991, Huettel \& Gust 1992a). Water soluble dye experiments have shown how streamlines within the sediment evolve from the periphery towards the centre of the chamber (Huettel \& Gust 1992a). This effect was discovered only recently, and it remains to be investigated in which sediments radial pressure gradients imposed by central stirring compromise benthic flux chamber measurements.

By using $\mathrm{Br}^{-}$as a conservative tracer we demonstrate the effect of stirring-induced pressure gradients in sediments of different permeabilities. The experiments are performed using relevant stirring rates in 2 benthic chambers for which the radial pressure gradients are well described. The sediment permeability at which advective transport was initiated by central stirring is defined.

\section{MATERIALS AND METHODS}

Sediment sampling and treatment. Five different sediments (Expts 1 to 5) were collected in early spring 1995 around the island of Sylt, North Sea, Germany. From each location, approximately $0.5 \mathrm{~m}^{3}$ of sediment was brought back to the laboratory. Macrofauna and larger obstacles were removed, and the sediment was homogenised with sea water from the sampling site (salinity $33 \%$ ). For Expts 6 to 9, silty sediment was mixed with commercially available sand (Sakret ${ }^{\text {Th}}$, grainsize 0.09 to $0.30 \mathrm{~mm}$ ) in order to obtain sediments of intermediary permeability. In these 4 experiments artificial sea water of $33 \%$ was used. The sediment was placed in large troughs at in situ temperature $\left(7.5^{\circ} \mathrm{C}\right)$ in a thermostated room, and sea water was added, leaving a total water height of approximately $15 \mathrm{~cm}$. The sediment was allowed to settle for $24 \mathrm{~h}$ before placement of the benthic chambers. Sediment samples were collected, and the grainsize distribution was determined by successive sieving (Table 1 ).

Chamber description and experimental set up. Experiments were performed with a square and a cylindrical benthic chamber. The square chamber is in use on the benthic lander Elinor (Glud et al. 1994b), but the same chamber with a slightly different stirring mechanism has been in use, or is in use, on several other benthic landers (Jahnke \& Christiansen 1989, Tengberg et al. 1995). The chamber has a $30 \times 30 \mathrm{~cm}$ square base with rounded corners and encloses a water column of 8 to $15 \mathrm{~cm}$ depending on its penetration depth (Fig. 1). The chamber is centrally stirred by an impeller consisting of 4 rods $(9.5 \times 1.3 \mathrm{~cm})$ connected to a central disk $5.5 \mathrm{~cm}$ in diameter (Fig. 1). During in situ deployments, the stirring rate of the impeller is kept at a fixed speed of between 7 to $12 \mathrm{rpm}$, depending on the experiment. These stirring rates produce a DBL thickness for oxygen of approximately 540 and $340 \mu \mathrm{m}$, respectively, over $91 \%$ of the base area (Glud et al. 1995). However, the 2 stirring rates also impose a radial pressure gradient on the incubated sediment, which was previously measured by Glud et al. (1995) whose results are reproduced in Fig. 2, Transects A and B.

The cylindrical chamber has a diameter of $19 \mathrm{~cm}$ and is centrally stirred by a flat disk $(17 \times 1 \mathrm{~cm})$ placed $7 \mathrm{~cm}$ above the sediment surface (Fig 1). Centrally stirred cylindrical chambers of different diameters have often been used as bell jars and are in use on several benthic landers (Tengberg et al. 1995). This chamber has an average DBL thickness of $300 \mu \mathrm{m}$ when stirred at $10 \mathrm{rpm}$ as measured from above with an $\mathrm{O}_{2}$ microelectrode (data not shown). The microelectrode was a 


\section{Square Chamber}

Side view

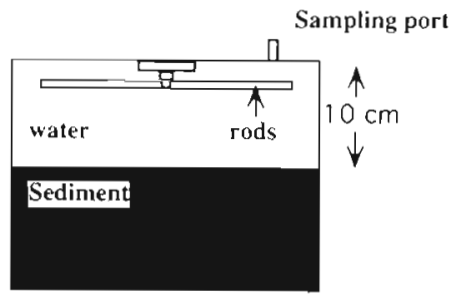

Cylindrical Chamber

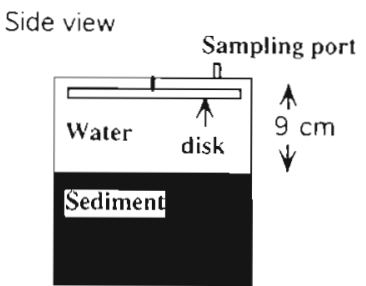

Top view
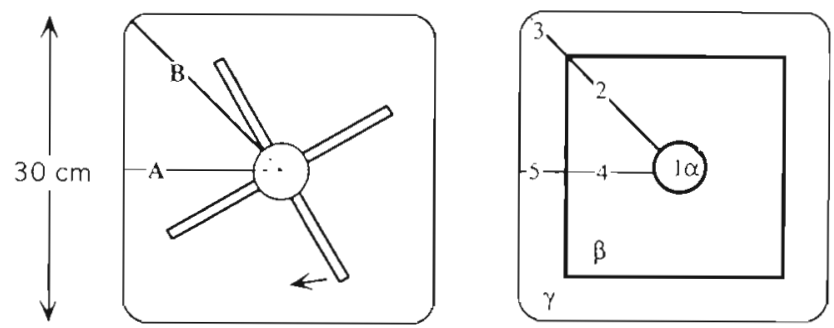

Top view

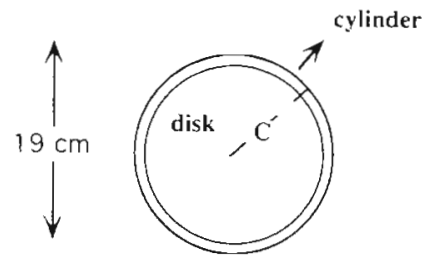

Fig. 1. Chambers and stirrers used in the experiments. The 3 transects (A, B, C) along which Glud et al. (1995) and Huettel (unpubl.) measured partial pressure gradients are indlcated. Positions of the recovered subcores $(1,2$, $3,4,5)$ used for porewater profiles and the areal $(\alpha . \beta, \gamma)$ distribution used for calculating the $\mathrm{Br}^{-}$recovery are also shown. For more details see text

Clark type with internal reference and a guard cathade as decribed by Revsbech (1989). The DBL value has to be taken as a minimum due to compression of the DBL imposed by the presence of an $\mathrm{O}_{2}$ microsensor (Glud et al. 1994a). Stirring rates of 7 and $12 \mathrm{rpm}$ in the cylindrical chamber generate the pressure gradients presented in Fig. 2, Transect C.

The 2 chambers were placed in the troughs, leaving an internal water height of $10 \mathrm{~cm}$ for the square and $9 \mathrm{~cm}$ for the cylindrical chamber (Fig. 1). The enclosed sediment surfaces were smoothed to avoid any microtopographic related effects. Sediments depths were $15 \mathrm{~cm}$ for the square chamber and $20 \mathrm{~cm}$ for the cylindrical chamber The chambers were then closed with a sealing lid and were stirred for 3 to $20 \mathrm{~h}$ before the solute tracer, $\mathrm{Br}^{-}(\mathrm{NaBr})$, was added to a final concentration of approximately $7 \mathrm{mM}$. The first water samples were taken 15 min after injection in order to allow an initial mixing of the tracer and the overlying water phase. Test experiments showed that this duration was sufficient to ensure complete mixing (data not shown). During the approximately 1000 min long incubations, 9 to 17 water samples of $2 \mathrm{ml}$ were taken from each chamber and frozen for later analysis. The sampled volume was replaced by water from outside the chamber. At the end of the incubations, the lids were removed, and $36 \mathrm{~mm}$ diameter sediment subcores were taken for porosity and permeability measurements. In addition, in 11 experiments with the square chamber, 5 subcores were taken along Transects A and $\mathrm{B}$ for porewater profiles of $\mathrm{Br}^{-}$(Fig. 1). The cores were taken at the following positions: in the centre

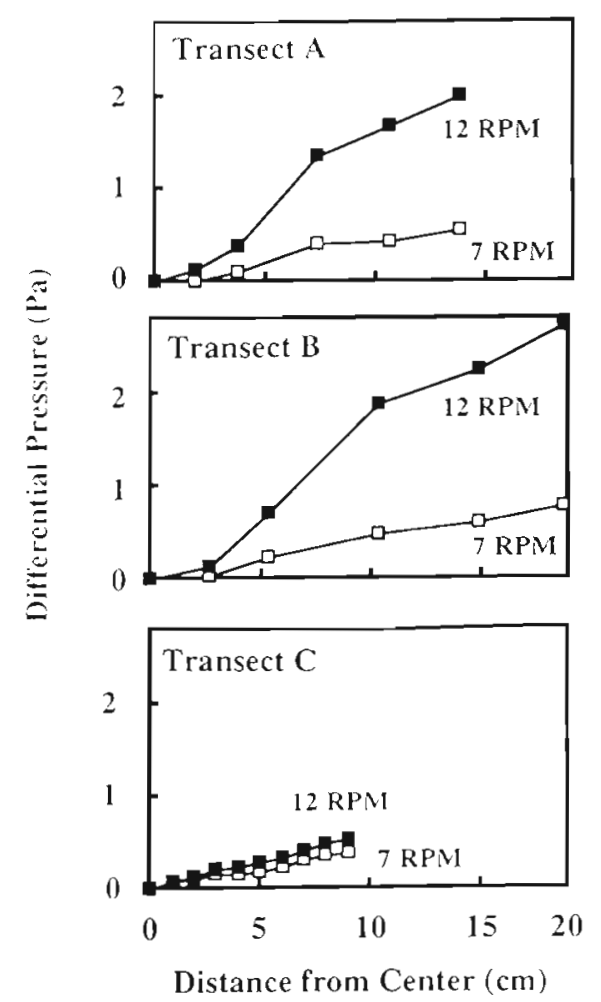

Fig. 2. Differential pressure gradients measured along Transects $A, B$ and $C$ in the square and the cylindrical chambers at stirring rates of 7 and $12 \mathrm{rpm}$. Water heights were 10 and $9 \mathrm{~cm}$, respectively. Data from Glud et al. (1995). Huettel (unpubl.) 
(Position 1), halfway on the diagonal towards the corner (Position 2), in the corner (Position 3), at the wall on Transect B (Position 5) and finally half way between Positions 1 and 5 (Position 4). Positions are indicated in Fig. 1. No cores were taken from the cylindrical chamber Immediately after recovery, the cores were sectioned into $0.5 \mathrm{~cm}$ slices, and the porewater was extracted through centrifugation and frozen for later analysis.

The $\mathrm{Br}^{-}$concentrations were determined with an anion chromatograph equipped with an autosampler (Waters ${ }^{\mathrm{M}}, 712$ WISP) and a Waters type A column. Water samples taken prior to the tracer addition provided the background $\mathrm{Br}^{-}$concentration and were used as blanks for later flux calculations. The precision of the $\mathrm{Br}^{-}$determination was $<0.1 \mathrm{mM}$

Previous studies have shown that $\mathrm{Br}^{-}$is a conservative tracer even in highly reduced sediments, that $\mathrm{Br}^{-}$is non-adsorbing in sediments, and that $\mathrm{Br}^{-}$addition has no effect on benthic metabolism (Martin \& Banta 1992, Sayles \& Martin 1995). Successive addition of sediment to $\mathrm{Br}^{-}$solutions did not change the dissolved $\mathrm{Br}^{-}$concentrations significantly, indicating that $\mathrm{Br}^{-}$ions did not adsorb to any of the sediments used (data not shown). Sediment porosities were determined at $0.5 \mathrm{~cm}$ depth intervals from the weight loss of sediment core segments of known weight and volume upon drying at $105^{\circ} \mathrm{C}$. The porosity was relatively constant with depth due to the initial homogenisation, only the surface had a slightly higher porosity in comparison to the deeper layers. For the calculations, we used the average porosities listed in Table 1 The sediment permeabilities were determined at in situ temperature (Table 1) by a constant head permeameter redesigned from Holme \& McIntyre (1971). Sediments consisting of relatively larger grain sizes generally had higher permeabilities (Table 1)

A total of 14 experiments were performed with the square chamber using stirring rates of 0,7 , and $12 \mathrm{rpm}$, and 6 experiments were conducted with the cylindrical chamber stirred at $12 \mathrm{rpm}$. In the experiments with $0 \mathrm{rpm}$, the overlying water was occasionally mixed to ensure an even distribution of $\mathrm{Br}^{-}$in the enclosed water volume.

Calculations. The sediment $\mathrm{Br}^{-}$uptake was determined from the decrease in water $\mathrm{Br}^{-}$concentration versus time by linear regression. For the square chamber, we also modelled $\mathrm{Br}^{-}$concentrations in the overlying water phase and in the sediment with the software program STELLA II ${ }^{T M}$ (2.2.2). The model was strictly diffusional and deviation between modelled and measured $\mathrm{Br}^{-}$concentrations was used as an indication for advective solute exchange. A single box model was designed in which the overlying water phase was regarded as 1 homogenised mixed layer, followed by a box representing the DBL. The upper $3 \mathrm{~cm}$ of the sediment were divided into 30 equal boxes. Solutes were assumed only to be transported between adjacent boxes by diffusion as calculated by Fick's first law of diffusion (Crank 1983). Further, it was approximated
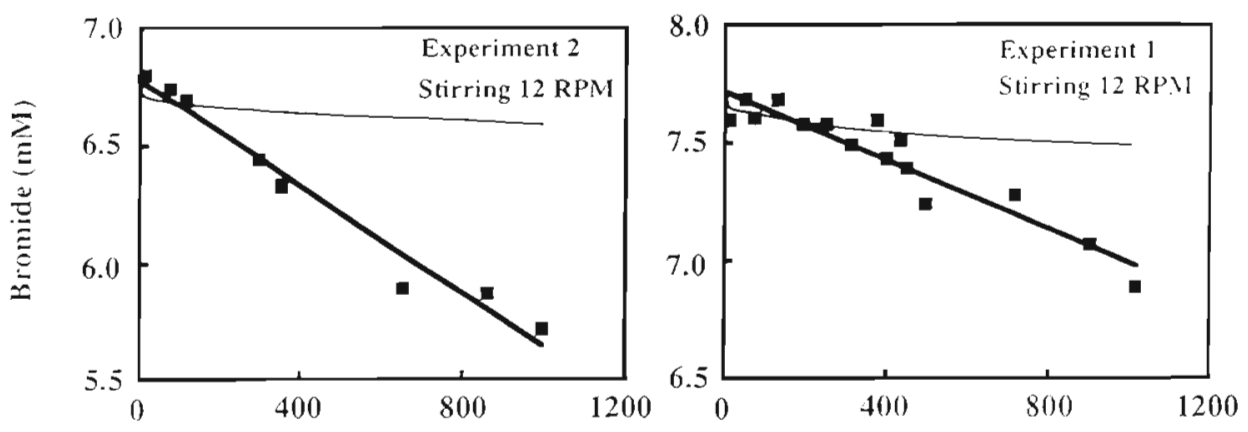

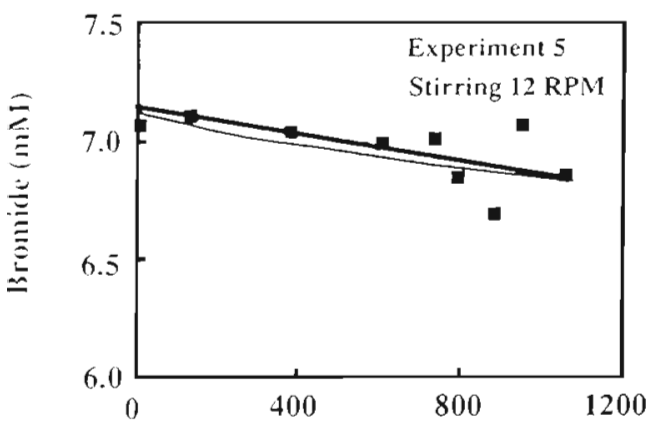

Time $(\mathrm{min})$

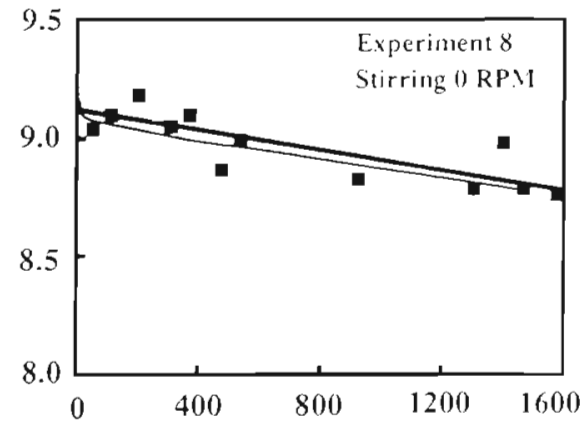

Time (min)
Fig. 3. Measured $\mathrm{Br}^{-}$concentration as a function of time in the square chamber during 3 incubations stirred at $12 \mathrm{rpm}$ (Expts 1, 2, and 5) and an incubation with occasional mixing of the overlying water (Expt 8). The fat line indicates the linear regression of the measured points, while the thin line expresses the modelled $\mathrm{Br}^{-}$concentration assuming diffusive exchange between water and sediment (DBL thickness $340 \mu \mathrm{m}$ ) 
that the DBL thickness in the square chamber was the same over the whole base area and had a thickness of 520 and $340 \mu \mathrm{m}$ for stirring rates of 7 and $12 \mathrm{rpm}$, respectively (see Glud et al. 1995). The diffusion coefficient for $\mathrm{Br}^{-}\left(D_{0}\right)$ at $7.5^{\circ} \mathrm{C}$ was calculated according to Li \& Gregory (1974) to be $1.34 \times 10^{-5} \mathrm{~cm}^{2} \mathrm{~s}^{-1}$ The porosity and tortuosity corrected sediment diffusion coefficient of $\mathrm{Br}^{-}$was derived from $D_{\text {sed }}=D_{0} \phi^{n}$, where $\phi$ is the measured porosity and $n=2$ (Ullmann \& Aller 1982).

For each incubation model run, the appropiate chamber water volumes, initial bromide concentrations and sediment porosities were applied. During the runs, time increments of $0.25 \mathrm{~min}$ were added until the actual incubation time was reached. The modelled $\mathrm{Br}^{-}$uptake was determined from the decrease in the modelled $\mathrm{Br}^{-}$concentration assuming a linear decrease from time 0 to the end of the incubation.

\section{RESULTS}

Within the first 1000 min after addition, the $\mathrm{Br}^{-}$concentration decreased linearly in all incubations. The measured and modelled $\mathrm{Br}^{-}$concentrations in the square chamber for 3 different sediments incubated at stirring rates of $12 \mathrm{rpm}$ are shown in Fig. 3. In Expts 1 and 2, the concentration of $\mathrm{Br}^{-}$decreased significantly faster than expected from the modelled diffusive uptake, while Expt 5 showed a close fit between modelled and measured $\mathrm{Br}^{-}$concentrations (Fig. 3). The sediment used in Expt 5 was silty and practically impermeable, while the sediments in Expts 1 and 2 were sandy and between 270 and 900 times more permeable (Table 1). Incubations without stirring, but occasional mixing of the overlying water also showed a close fit between measured and modelled diffusive $\mathrm{Br}^{-}$concentrations, even in the highly permeable sediments (Fig. 3, Expt 8; Table 2).

The porewater profiles of $\mathrm{Br}^{-}$recorded along Transect $A$ at the end of Expts 2 and 5 are shown in Fig. 4 and are compared with modelled $\mathrm{Br}^{-}$distribution assuming diffusive exchange between water and sediment. In Expt 2, the radial pressure gradient induced by the central stirring in the square chamber caused an advective porewater flow, transporting $\mathrm{Br}^{-}$deeper than $7 \mathrm{~cm}$ into the sediment at the corners of the chamber (Position 3). Advective $\mathrm{Br}^{-}$uptake decreased towards the centre of the chamber (Fig. 4). The modelled purely diffusive $\mathrm{Br}^{-}$uptake resulted in a $\mathrm{Br}^{-}$penetration depth of approximately $2.5 \mathrm{~cm}$ at the end of the incubation (Fig 4) In a sediment with low permeability (Expt 5) the porewater profiles measured along Transect $A$ all fitted well with the profiles modelled assuming pure diffusive transport (Fig. 4). The porewater profiles along Transect $B$ showed the same pattern (data not shown).

The model-generated diffusive $\mathrm{Br}^{-}$uptake in the square chamber (12 $\mathrm{rpm}$ ) equalled $3.3 \mathrm{mmol} \mathrm{m}^{-2} \mathrm{~d}^{-1}$. This was assuming the following conditions for an average chamber incubation: $10 \mathrm{~cm}$ water height, a DBL thickness of $340 \mu \mathrm{m}$, the average porosity profile and an initial $\mathrm{Br}^{-}$start concentration of $7.1 \mathrm{mM}$. Measured $\mathrm{Br}^{-}$uptake rates from 20 chamber experiments are presented in Table 2. Experiments performed with relatively impermeable sediments (Expts 5 and 7 in the square chamber) and experiments without central stirring (Expts 6, 8 and 9 in the square chamber) 


\section{Experiment 2}
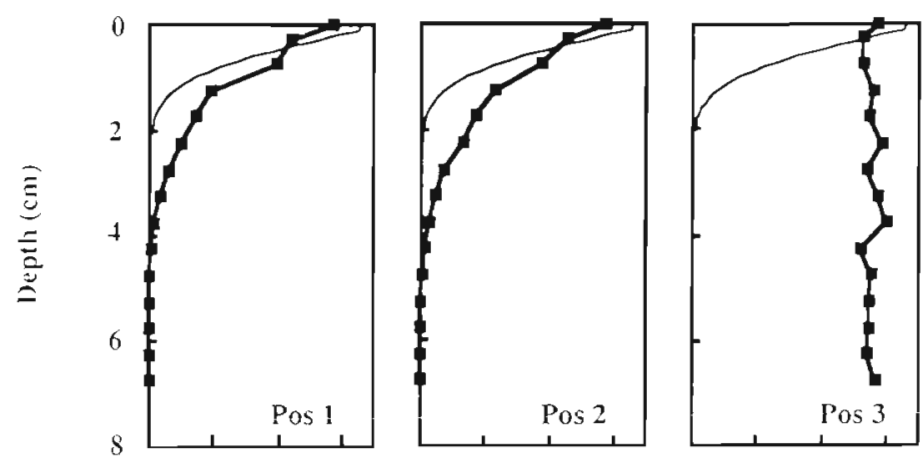

\section{Experiment 5}

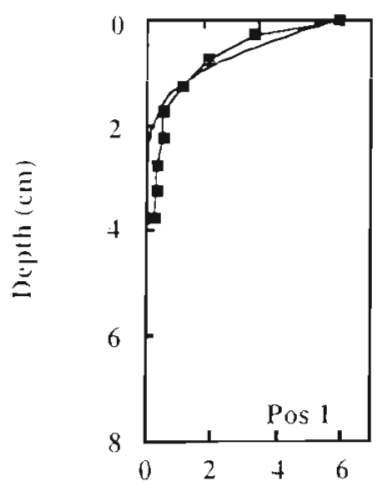

Bromide (mM)

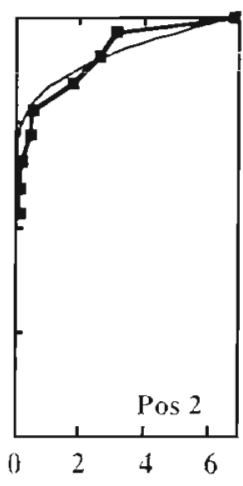

Bromide ( $m \mathrm{M})$

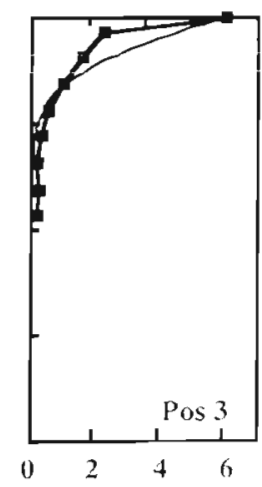

Bromide (mM)
Fig. 4. Measured and modelled (thin line) porewater profiles of Br along Transect $A$ in the square chamber stirred at 12 rpm for Expts 2 and 5

resulted in measured $\mathrm{Br}^{-}$uptake rates close to the modelled value (Fig. 5, Table 2). As permeability increased above a critical value (see below) the $\mathrm{Br}^{-}$uptake rates began to exceed the modelled rates. The advective $\mathrm{Br}^{-}$ uptake increased with the stirring rate and the sediment permeability (Fig. 5, Table 2)

For a given chamber, at a given stirring rate, the measured $\mathrm{Br}^{-}$uptake decreased exponentially with the sediment permeability. By linear extrapolation on the semi-log plot of Fig. 5, the critical permeability at which advective $\mathrm{Br}^{-}$uptake was initiated could be determined. For the square chamber the critical permeability was approximately $2 \times 10^{-12} \mathrm{~m}^{2}$ for stirring rates of $12 \mathrm{rpm}$ and $1 \times 10^{-11} \mathrm{~m}^{2}$ for stirring rates of $7 \mathrm{rpm}$. For the cylindrical chamber the critical permeability value was reached at an intermediate value of $5 \times 10^{-12} \mathrm{~m}^{2}$ at a stirring rate of $12 \mathrm{rpm}$ (Fig. 5 . Table 2).

In order to estimate the total content of $\mathrm{Br}^{-}$in the sediment at the end of the incubations, the base area of the square chamber was divided into 3 sections; a central (Area $\alpha$ ), an intermediate (Area $\beta$ ) and a border area (Area $\gamma$ ), which are indicated on Fig. 1 Area $\alpha$ was represented by Core 1, Area $\beta$ by Cores 2 and 4 , and Area $\gamma$ by Cores 3 and 5 . The areal distribution was arbitrary, but Area $\alpha$ was defined as a centre area of a diameter 2 times the subcore, the borders between Areas $\beta$ and $\gamma$ were put halfway between cores obtained at Positions 2 and 3 and halfway between Positions 4 and 5. In those cases where the measured $\mathrm{Br}^{-}$uptake could be described by pure diffusion, the total amount of $\mathrm{Br}^{-}$recovered in the sediment accounted for $101 \pm 17 \%$ (Table 2). However, when advective porewater transport was involved only $49 \pm 17 \%$ was recovered in the sediment, assuming the area subdivisions given above (Table 2). The reason for this was a combination of incomplete recovery of the $\mathrm{Br}$ porewater profiles and the fact that the measured porewater profiles only poorly reflected the real distribution of $\mathrm{Br}^{-}$in the sediment (see below).

\section{DISCUSSION}

In the case of diffusive benthic uptake of a conservative tracer such as $\mathrm{Br}^{-}$, the concentration in the overlying water phase is expected to decrease exponentially (Crank 1983). However, with our precision of approximately $0.5 \%$ for a single $\mathrm{Br}^{-}$determination, and a total decrease in the $\mathrm{Br}^{-}$concentrations in the range of 5 to $15 \%$ during the appoximately $1000 \mathrm{~min}$ incubations, it was not possible to distinguish between an exponential or a linear decrease in the $\mathrm{Br}^{-}$concentrations. Similary, in normal benthic flux chamber determinations, an initial linear decrease (or increase) in solute concentrations is usually assumed (e.g. Hall et al, 1989). During incubations with advective porewater transport, the change in $\mathrm{Br}^{-}$concentration in the overlying water was also indistinguishable from a linear decrease (Fig. 3). This was due to the relatively short incubation time used in our experiments. The modelled $\mathrm{Br}^{-}$concentrations in the overlying water phase decreased exponentially, but for comparison to the measured $\mathrm{Br}^{-}$uptake we just used the difference between the start and end values of the modelled concentrations

At stirring rates of 8 and $12 \mathrm{rpm}$ the DBL in the square chamber was measured to be $521 \pm 54 \mu \mathrm{m}$ and $343 \pm 25 \mu \mathrm{m}$, respectively, over $91 \%$ of the base area using $\mathrm{O}_{2}$ microelectrodes (Glud et al. 1995) These measurements were performed by approaching the 


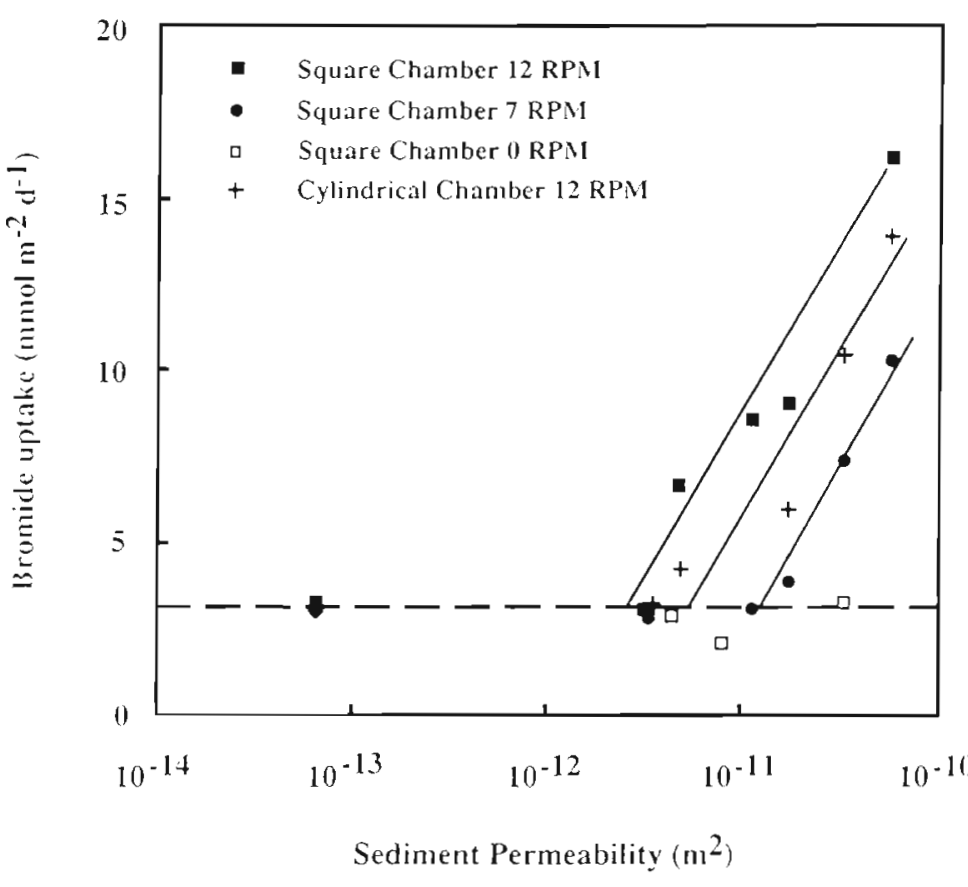

Fig. 5. Measured bromide uptake rates as a function of the sediment permeability. Dotted line indicates the modelled diffusive $\mathrm{Br}^{-}$uptake (for details see text). Solid lines are hand drawn

DBL from below and thereby avoiding the DBL compression imposed by microelectrodes (Glud et al. 1994a). The DBL thickness is solute dependent, but the upper boundary of DBL is usually defined as where the eddy diffusion coefficient, $K$, becomes smaller than the diffusion coefficient, $D_{0}$ (Boudreau \& Guinasso 1982). The DBL thickness for $\mathrm{Br}^{-}$in the experimental conditions must have been close to the DBL thickness for $\mathrm{O}_{2}$, since the eddy diffusivity is solute independent (Shaw \& Hanratty 1977) and since the diffusion coefficients for the 2 solutes differ by less than 3\% (Li \& Gregory 1974). The thickness of the DBL had only a minor influence on the measured diffusive $\mathrm{Br}^{-}$uptake. In Expt 7, where the $\mathrm{Br}^{-}$uptake was driven by diffusion, the increase in the stirring rate from 7 to $12 \mathrm{rpm}$ did not increase $\mathrm{Br}^{-}$uptake significantly (Table 2). Also, with no stirring, where the DBL. was poorly defined, the measured $\mathrm{Br}^{-}$uptakes came close to the modelled $\mathrm{Br}^{-}$uptake rates as well as those measured at stirring rates of 7 and $12 \mathrm{rpm}$ (Table 2). Model runs with different DBL thicknesses also showed a negligible effect on the diffusive $\mathrm{Br}^{-}$uptake after $1000 \mathrm{~min}$ of incubation. The DBL thickness will regulate how fast $\mathrm{Br}^{-}$is taken up by the sediment immediately after tracer addition. However, as the $\mathrm{Br}^{-}$ penetration depth increases, the relative impedance imposed by the DBL decreases correspondingly. From the measured and modelled data it was clear that after a 1000 min incubation and an approximate $\mathrm{Br}^{-}$ penetration depth of $2.5 \mathrm{~cm}$ the effect of the DBL thickness was negligible.

The amount of $\mathrm{Br}^{-}$recovered in the sediment after incubations, dominated by diffusive $\mathrm{Br}^{-}$uptake, balanced the amount of $\mathrm{Br}^{-}$ missing in the water phase. This validated the diffusive approach and indicated that the chambers had no leaks. By contrast, in cases of an advective $\mathrm{Br}^{-}$uptake, only appoximately half of the $\mathrm{Br}^{-}$missing in the water phase was recovered in the sediments. However, in some experiments the pressure induced advection transported $\mathrm{Br}^{-}$deeper into the sediment than the reach of the $7 \mathrm{~cm}$ long subcores (Fig. 4), and an incomplete recovery was therefore to be expected. The distribution of $\mathrm{Br}^{-}$within the sediment as driven by the advective pore water transport is time dependent, and the extent to which cores recovered at Positions 1 to 5 represent the assumed areal distribution will be a function of the incubation time and the permeability of the sediment. The tracer distribution in permeable sediments is much more complex in a square chamber as compared to a cylindrical chamber with a strictly radial pressure gradient. It is thus not to be expected that the 5 cores recovered from the square chamber represent the average conditions in the sediment in the case of permeable sediment.

The magnitude of the radial pressure gradient induced by central stirring for a given chamber is mainly a function of stirring rate and water height. Increasing the stirring rate from 7 to $12 \mathrm{rpm}$ in the square chamber clearly increased $\mathrm{Br}^{-}$uptake in the permeable sediment. Furthermore, the sediment permeability, where no significant advective porewater transport occurred, was reduced by almost 1 order of magnitude at the increased stirring rate. By contrast, when highly permeable sediment was placed in the chamber and no stirring but only occasional mixing was applied, the $\mathrm{Br}^{-}$uptake could be described by diffusion, confirming that the radial pressure was stirring induced. The cylindrical chamber had a different stirrer and a smaller diameter than the square chamber and the stirring was less vigorous even at the same rotation speed. For that reason, the cental stirring induced a lower advective $\mathrm{Br}^{-}$uptake in permeable sediments when incubated at the same stirring rate. A lower stirring rate in the square chamber could, however, more than compensate for this (Fig. 5). We did not vary the water height in our experiments; however, previous studies have shown that increasing the water height at a constant stirring rate reduces the radial pressure gradient (Huettel \& Gust 1992, Glud et al. 1995). 
Most chambers used for benthic flux studies, cylindrical as well as square ones, have sizes between the 2 chambers investigated in this study. Even though the design of the stirring devices may differ, it is plausible that radial pressure gradients of comparable size exist in most chambers stirred at rates resulting in an in situlike DBL thickness. Advective porewater transport is a natural phenomenon in permeable sediments, where sediment topography can induce local pressure gradients of 1 to $3 \mathrm{~Pa}$ (Thibodeaux \& Boyle 1987. Huettel \& Gust 1992b, Huettel et al. 1996). As demonstrated, central stirring in benthic chambers can induce comparable pressure gradients. In general, data obtained by benthic chambers in sediments with a permeability exceeding $2 \times 10^{-12} \mathrm{~m}^{2}$, have to be evaluated with extreme care. By lowering the stirring rate or changing the chamber design the critical pemeability value can be increased by at least 1 order of magnitude (Fig. 5). This is, however, a trade-off. In sediments, where the DBL thickness acts as a diffusive barrier for the benthic exchange, the applied stirring rate has to impose a DBL thickness close to the in situ value. Further, decreasing the size of a benthic chamber increases artefacts caused by wall effects and decreases the number of undisturbed macrofaunal organisms enclosed in the sediment during an incubation.

The present study allowed evaluation of the potential effects of stirring-induced advective porewater transport for a given incubation if the sediment permeability is measured. The measurements were, however, performed with homogenised sediment and without macrofauna. It is well known that macrofauna, through their feeding activity, can increase benthic solute exchange significantly (e.g. Aller \& Yingst 1985); however, the presence of macrofauna may also increase the sediment permeability (e.g. pellet formation, funnels and burrows). Burrow structures in deep sediment layers will not be affected by the stirring induced water flow, but in the case of U-shaped structures an enhanced flushing of the burrows must be expected. The effect on the measured solute exchange will be dependent upon the orientation of the burrow relative to the chamber geometry and of course on the potential burrow inhabitant and its feeding behaviour Even though a simple permeability measurement now can exclude an advective porewater transport during a chamber incubation, the effect of radial pressure stimulated flushing of burrows is difficult to evaluate and needs attention when 'state of the art' in situ flux and bioirrigation measurements are presented.

Acknowledgements. We thank Susanne Kloser and Martina Schütte for skillful technical assistance during the Br-analysis and the experiments. Further, thanks to Axel Krack for practical assistance in preparing the experiments. Thanks to
Don Canfield for constructive criticism of the manuscrpt. This study was supported by The Max Planck Society.

\section{LITERATURE CITED}

Aller RC, Yingst JY (1985) Effects of marine deposit-feeders Heteromastus filiformus (Polychaeta), Macoma baltica (Bivalvia), and Tellina texana (Bivalvia) on averaged sedimentary solute transport, reaction rates, and microbial distribution. J Mar Res 43:615-645

Archer D, Emerson S, Smith CR (1989) Direct measurements of the diffusive sublayer at the deep sea floor using oxygen microelectrodes. Nature 340:623-626

Berelson WM, Hammond DE (1986) The calibration of a new free-vehicle benthic flux chamber for use in the deep sea. Deep Sea Res 33:1439-1454

Booij K, Helder W, Sundby B (1991) Rapid redistribution of oxygen in sandy sediment induced by changes in the flow velocity of the overlying water. Neth J Sea Res 28: 149-165.

Boudreau BP, Guinasso NL Jr (1982) The influence of a diffusive sublayer on accretion. dissolution, and dragenesis at the sea floor. In: Fanning KA, Manheim FT (eds) The dynamic environment at the ocean floor. Lexington Books, Lexington, MA, p 115-145

Buchholz-ten Brink MRB, Gust G, Chavis D (1989) Calibration and performance of a stirred benthic chamber Deep Sea Res 36:1083-1101

Crank J (1983) The mathematics of diffusion. Clarendon Press, Oxford

Devol AH (1987) Verification of flux measurements made with in situ benthic chambers. Deep Sea Res 34: $1007-1026$.

Glud RN, Gundersen JK, Jorgensen BB, Revsbech NP (1994a) Effects on the benthic diffusive boundary layer imposed by microelectrodes. Limnol Oceanogr 39:462-467

Glud RN, Gundersen JK, Jargensen BB, Revsbech NP, Schulz HD (1994b) Diffusive and total oxygen uptake of deep-sea sediments in the eastern South Atlantic Ocean: in situ and laboratory measurements. Deep Sea Res 41:1767-1788

Glud RN, Gundersen JK, Revsbech NP. Jørgensen BB, Huettel $M(1995)$ Calibration and performance of the stirred flux chamber from the benthic lander Elinor. Deep Sea Res 42:1029-1042.

Gundersen JK, Jørgensen BB (1990) Microstructure of diffusive boundary layers and the oxygen uptake of the sea floor. Nature 345:604-607

Hall POJ, Anderson LG, Rutgers van der Loeff MM, Sundby B. Westerlund SFG (1989) Oxygen uptake kinetics in the benthic boundary layer. Limnol Oceanogr 34:734-746

Holme NA, McIntyre AD (1971) Methods for the study of marine benthos. Blackwell Scientific Publications, Oxford, p $47-49$

Huettel M, Gust G (1992a) Solute release mechanısms from confuned sediment cores in stirred benthic chambers and flume flows. Mar Ecol Prog Ser 82:187-197

Huettel M. Gust G (1992b) Impact of bioroughness on the interfacial solute exchange in permeable sediments. Mar Ecol Prog Ser 89:253-267

Huettel M, Ziebis W, Forster S (1996) Flow-mduced uptake of particulate matter in permeable sediments. Limnol Oceanogr 41:309-322

Jahnke RA, Christiansen MB (1989) A frue-vehicle benthıc chamber instrument for sea floor studies. Deep Sea Res 36 : $625-637$

Jørgensen BB, Des Marais D (1990) The diffusive boundary 
layer of sediments: oxygen microgradients over a microbial mat. Limnol Oceanogr 35:1353-1355

Li YH, Gregory S (1974) Diffusion of lons in deep-sea sediments. Geochim Cosmochim Acta 38:703-714.

Martin WR, Banta CT (1992) The measurements of sediment irrigation rates: a comparison of the $\mathrm{Br}$ - tracer and ${ }^{222} \mathrm{Rn} /{ }^{226} \mathrm{Rn}$ disequilibrium techniques. J Mar Res 50: $125-154$

Pamatmat MM, Banse K (1969) An instrument for measuring subtidal benthic metabololism in situ. Limnol Oceanogr $13: 537-540$

Revsbech NP (1989) An oxygen microelecsrode with a guard cathode. Limnol Oceanogr 34:474-478

Santschi PH, Bower P, Nyffeler UP, Azevedo A, Broecker WS (1983) Estimates of the resistance to chemical transport posed by deep-sea boundary layer Limnol Oceanogr 28: 899-912

Sayles FL, Dickinson WH (1991) The ROLAI²D lander: a benthic lander for study of exchange across the sedimentwater interface. Deep Sea Res 38:527-545

Sayles FL, Martin R (1995) In situ tracer studies of solute transport across the sediment-water interface at the

This article was submitted to the editor
Bermuda Time Series site. Deep Sea Res 42:31=52

Shaw DA. Hanratty T (1977) Turbulent mass transfer rates to a wall of large Schmidt numbers. J Am Inst Chem Eng 23: $28-37$

Smith KL Jr, Clifford CH, Eliason AH, Walden B, Rowe GT, Teal JM (1976) A free vehicle for measuring benthic community metabolism. Limnol Oceanogr 21:164-170

Smith KL Jr, Hinga KR (1983) Sediment community respiration in the deep sea. In: Rowe GT (ed) The Sea, Vol 8. Wiley, New York, p 331-370

Tengberg A, De Bovee F, Hall P, Berelson W, Cicceri G, Crassous $P$, Devol A, Emerson S, Glud RN, Graziottin F, Gundersen JK. Hammond D, Helder W, Holby $O$, Jahnke R, Khripounoff A, Nuppenau V. Plannkuche O, Reimers $C$, Rowe G. Sahamı A, Sayles F, Schuster M, Wehrli B, de Wilde P (1995) Benthic chamber and profile landers in oceanography - a review of design, technical solutions and functioning. Prog Oceanogr 35:253-294

Thibodeaux LJ, Boyle JD (1987) Bedform-generated convective transport in bottom sediment. Nature 325:341-343

Ullman WJ, Aller RC (1982) Diftusion coefficients in nearshore manne sediments. Limnol Oceanogr 27:552-556

Manuscript first received: March 25, 1996

Revised version accepted: May 17, 1996 